\title{
The Torah in Matthew: Still valid, yet to be interpreted alternatively
}

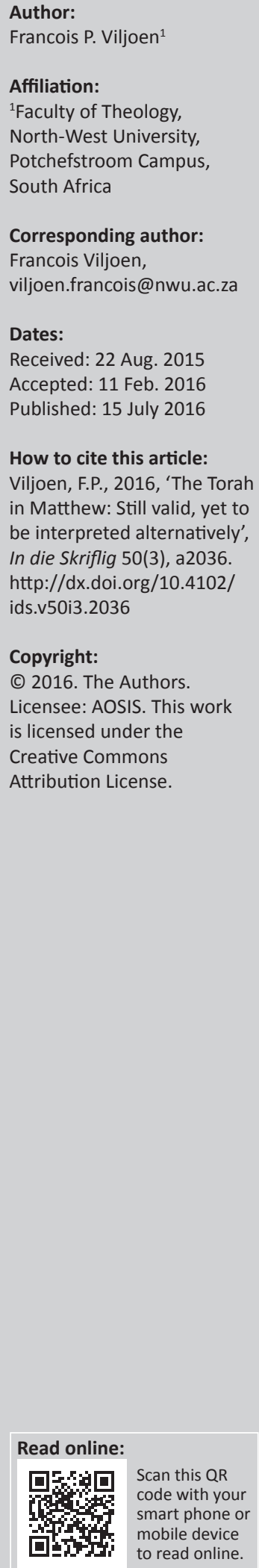

It seems that Matthew intentionally emphasises the importance of the Torah for his community. He highlights Jesus' high regard for the continuing validity of the Torah. However, he demonstrates that Jesus interpreted the Torah differently from Judaist groups of those times. The intention of this article is to demonstrate this significant role of the Torah in the first Gospel. It is argued that the Torah holds a central position in Matthew and that the Torah continues to remain valid, but that Jesus teaches and enacts an alternative interpretation of the Torah.

\section{Introduction}

The Torah forms a significant theme in Matthew's Gospel, much more than in any of the other synoptic Gospels. It forms the focus of the Sermon on the Mount with its strong Sinai typology, and disputes about the Torah are repeated throughout the Gospel (e.g. Mt 12:1-14; 15:1-9 and 22:34-40).

It seems that the importance and interpretations of the Torah were contentious issues in the society in which this Gospel was written. It seems that Matthew intentionally emphasised the importance of the Torah for his community. He highlighted Jesus' high regard for the continuing validity of the Torah. However, he demonstrates that Jesus interpreted the Torah differently from Judaist groups of those times, such as the Pharisees. He argues that Jesus had the superior knowledge and authority to do so. It might be that other Judaist groups in their society, presumably the Pharisees, accused Matthew's community of disregard for the importance of the Torah and that Matthew intended to defend the position of his community.

The intention of this article is to demonstrate the significant role of the Torah in the first Gospel. The article argues that:

- the Torah holds a central position in Matthew

- the Torah continues to remain valid; but that

- Jesus teaches and enacts an alternative interpretation of the Torah.

The research proposes that the central role of the Torah must be seriously considered when reading the first Gospel.

\section{The Torah holds a central position}

The central position of the Torah in Matthew is especially notable from the way Jesus teaches the Torah and proceeds to enact the intention of the Torah.

\section{Jesus teaches the Torah}

The Sermon on the Mount especially signifies the importance of the Torah in Matthew. This sermon holds a prominent position in the Gospel as the first of five great discourses. These discourses are the Sermon on the Mount (Mt 5-7), the missionary charge (Mt 10:5-42), the parables discourse (Mt 13:3-52), instructions to the community (Mt 18:3-35), and the woes and eschatological discourse (Mt 23-25) (cf. Davies \& Allison 2004a:60). Combrink (1983:61-90) identifies a chiastic structure between the discourses as indicated in Box 1.

Note: Some of the research and writing of this article is based on work previously published by the author. Please see links to published work: http://indieskriflig.org.za/index.php/skriflig/article/view/1751/2486

http://www.ve.org.za/index.php/VE/article/view/682/1228

http://www.hts.org.za/index.php/HTS/article/view/1300/3350 
BOX 1: Chiastic structure of Matthew's discourses.

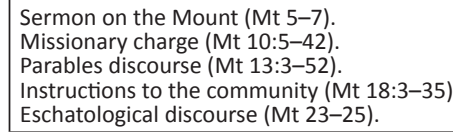

The Sermon on the Mount (Mt 5-7) parallels the woes and the eschatological discourse (Mt 23-25). The missionary charge (Mt 10) parallels the community discourse (Mt 18). The parables discourse (Mt 13) is framed by the above-mentioned parallels.

Each of these discourses is followed by a narrative on the actions or sayings of Jesus that are related to the preceding discourses. These five discourses serve as main building blocks or the architectonical structure of the first Gospel. It seems that this fivefold structure could be a deliberate imitation of the Pentateuch to indicate the relation between Matthew's Gospel and pentateuchal material (cf. Bacon 1930:48).

In the Sermon on the Mount, Matthew alludes to Moses when presenting Jesus (cf. Allison 1993:137-270; Floor 1969:34). Right from the beginning of this carefully composed sermon, the Sinai typology is significant as Jesus went up the mountain to teach (Mt 5:1-2). This opening creates an anticipation of a new revelation to be delivered by a new Lawgiver (Loader 1997:165). This expectation is met when Jesus declares the purpose of his coming with his 'I have come'-sayings with regard to the law in Matthew 5:17 (Osborne 2010:181)2 and his repeated reference to the meaning and intention of the law in the sermon inter alia with his sixfold elaboration on stipulations of the law (on murder, adultery, divorce, oaths, retaliation and neighbourly love; Mt 5:21-47; cf. Osborne 2010:187) ${ }^{3}$ and his disapproval of hypocritical righteousness in charity, praying and fasting (Mt 6:1-18; cf. Weren 1994:73). ${ }^{4}$

In Judaism it was a well-known concept that the mosaic character could transmigrate to later legislators and teachers (e.g. Ezekiel). According to 4 Ezra 14 the scribe received the old revelation of Sinai plus additional new revelations (Allison 1993:185). Within this convention Jesus is portrayed as a teacher and revealer comparable to Moses.

Beyond the Sermon on the Mount, Jesus' teaching on the Torah echoes in several other passages as well, for Matthew as a 'new Pentateuch'. Though scholarship, since this publication has critiqued Bacon's assumption (cf. Osborne 2010:4041), it should be acknowledged that his proposal pays tribute to the five discourses of Jesus in this Gospel.

2.These words are probably both polemically and apologetically intended (Betz 1985:40). It seems that Matthew with these words anticipates charges against his community's understanding of the law (Davies \& Allison 2004a:481).

3.The six theses (or examples) are all introduced by variations of a repetitive formula (you have heard). Each of these statements is then followed by an antithetical (you have heard). Each of these statements is then followed by an antithetica response with ' the emphatic 'but I tell you', is the authoritative and alternative teaching of Jesus. Osborne (2010:187) labels this alternative teaching the 'Torah of the Messiah'. Thi form antithetical debate often occurs in early Jewish text (cf. Foster 2004:80). By contrasting the viewpoints of insiders with group would promote its own viewpoint.

4.These three examples were central to Jewish piety during the Second Temple Period (Betz 1995:338; Morris 1992:135). example Matthew 15:1-205 and 22:34-40. ${ }^{6}$ Significantly the Gospel concludes with Jesus' Great Commandment that his disciples should go and make disciples by teaching them to obey everything he has commanded them (Mt 28:18-20; cf. Meier 1976:168; Saldarini 1994:79). Jesus is depicted as the One who taught the law and commands his disciples to teach others the contents of what he taught.

\section{The teacher of the Torah enacts the Torah}

Once the Matthean Jesus ended the Sermon on the Mount, with its strong emphasis on the meaning of the Torah, Matthew tells that Jesus came down from the mountain (Mt 8:1) as Moses once did from Mount Sinai (Ex 19:14; 32:1; 34:29). Matthew thus apparently draws a parallel between Jesus and Moses, and the Mount of Jesus' sermon and Mount Sinai (Carter 2000:198; Davies \& Allison 2004a:9; Luz 2001:5). The impressive and authoritative teacher of the law found in the discourse is subsequently presented in the narrative as going into action with a series of 10 miracles (Mt 8-9) to demonstrate how the law should be practiced. Grundmann fittingly describes the Sermon on the Mount as 'das Wirken des Christus Jesus durch das Wort' [the work of Christ Jesus through the word] (Grundmann 1971:111) and the miracles that follow as 'das Wirken des Christus Jesus durch die Tat' [the work of Christ Jesus through the deed] (Grundmann 1971:245).

Matthew links the Sermon on the Mount and the narrative describing Jesus' 10 miracles with two summaries of the teaching and the miracles Jesus performed (Mt 4:23-25 and 9:35), forming some sort of compositional frame around them (Morris 1992:186; Senior 1998:94; Talbert 2010:109) as indicated in Box 2 ('The summaries and composition of miracle stories in Matthew').

The healing narrative describes a series of 10 miracle stories. Matthew tells a series of 9 healing miracles stories (Mt 8-9 ${ }^{7}$ and a nature miracle of Jesus stilling the storm (Mt 8:23-27), making a total of 10 (cf. Weren 1994:83). This block of 9 or 10 miracles, in sets of three, are separated by two discipleship sections (Mt 8:18-22; 9:9-17; Davies \& Allison 2004b:6; Kingsbury 1988:59; Osborne 2010:332; Overman 1996:112) as outlined in Table 1.

As Moses performed signs and miracles, so did Jesus. Jesus can therefore be regarded as the new Moses. As early as 1927

5.In Matthew 15:1-20 the oral iaw as observed and developed by the Pharises, is in dispute (cf. Evans 2012:299). Jesus responds to the accusation made by the Pharisees and the scribes that his disciples do not observe the tradition of handwashing. In this dispute story two ideas are interwoven, namely the locus of impurity (external or internal), and the tradition of the elders versus the Word of God. The fact that Matthew's Jesus contrasts the tradition of the elders with the Word of God implies that he doesn't regard these traditions as coming from God.

6.Matthew 22:34-40 describes yet another scene where the Jewish leaders confront Jesus about the Torah. This scene concludes a series of hostile interrogations (Streitgesprächen): the first on whether one should pay tax to the caesar (Mt 22:15(22) thespachen). the first on whether one should pay tax to the caesar (Mt 22:1522), the second on who the husband would be after the resurrection of a woman who had seven husbands on earth (Mt 22:23-33); and thirdly on which commandment of
the Torah should be regarded as the greatest (cf. Meier 2009:482, 486).

7.The nine healings are that of the leper, the centurion's servant, Peter's mother-inlaw, the Gaderene demoniacs, the paralysed man, the ruler's daughter, the woman with blood flow, the blind men and the dumb man. 
BOX 2: The summaries and composition of miracle stories in Matthew.

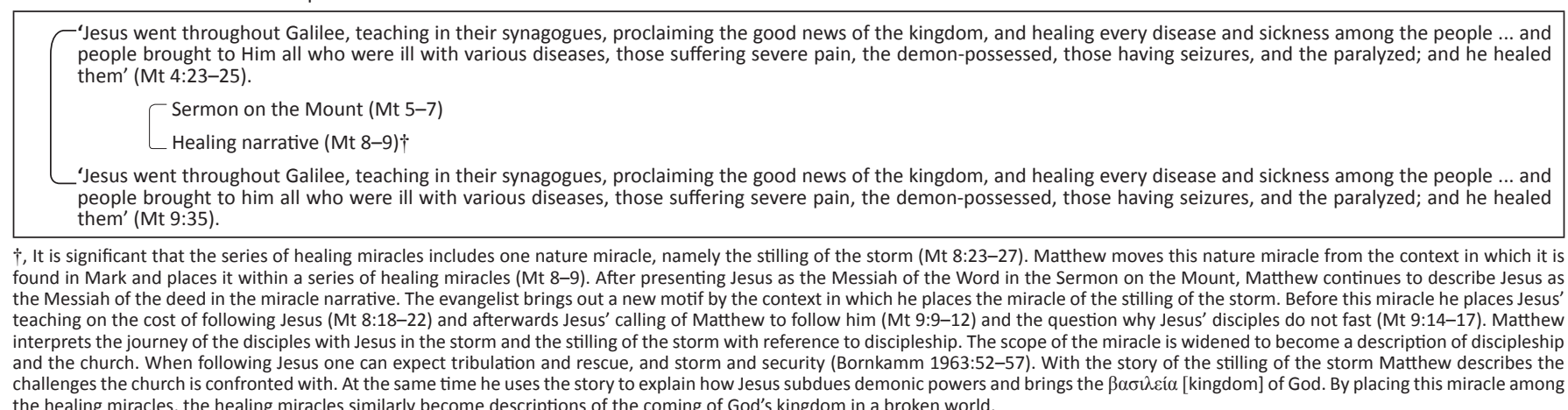
the healing miracles, the healing miracles similarly become descriptions of the coming of God's kingdom in a broken world.

TABLE 1: Miracle and discipleship sections of Matthew's healing narrative.

\begin{tabular}{lccc}
\hline Miracles 1, $\mathbf{2}$ and $\mathbf{3}$ & Discipleship & Miracles 4, 5 and 6 & Discipleship \\
\hline Matthew 8:1-17 & Matthew 8:18-22 & Matthew 8:23-9:8 & Matthew 9:9-17 \\
\hline
\end{tabular}

Klostermann (1927:72) has argued that Jesus' 10 miracle stories allude to the 10 miracles of the exodus from Egypt (Ex 7-12) and can be interpreted as a new Moses typology. ${ }^{8}$ However, these healing and saving miracles of Jesus significantly contrast with the plagues in Egypt, which signifies God's plan of salvation in and through Jesus. The miracle narratives depict the authority ( $\dot{\varepsilon} \xi o v \sigma i ́ \alpha)^{9}$ of Jesus over illness, nature, demons, paralysis, disabilities and death (Osborne 2010:280).

\section{The Torah continues to remain valid}

Matthew frequently affirms that the Torah continues to remain valid. It seems that Matthew intends to refute accusations that Jesus abrogated the Torah.

\section{The importance of the Torah in Jewish society}

Bearing in mind the religious world of the Matthean community, it seems that a reconsideration of the correct interpretation of the Torah was an important and contentious issue in those times. Rome destroyed Jerusalem, the temple and the temple service in 70 CE This left the Jewish community bewildered. The Jews struggled to come to terms with their loss and probably with the question of whether the earlier exile and recent destruction of the temple were the punishment of God for their sins. If the destruction was God's punishment for sin, they had to consider how to know God's will with certainty in order to avert similar disasters in future. This resulted in many significant reformulations of important theological ideas and religious practices. Various Jewish groups debated questions about the meaning and practice of the Torah and about the authority to interpret it (Carter 2000:140; Cohen 2006:123; Foster 2004:2; Saldarini 1994:5). Temple-based worship was replaced by small localised groupings with a mutual emphasis on Torah

8.Micah prophesied that Israel and Judah would experience a new exodus from exile 'As in the days when you came out of Egypt, I will show them my wonders' (Mi 7:15). Some early Christians applied this prophecy to the ministry of Jesus: As Moses did signs and miracles, so also did Jesus. And there is no doubt but that the likeness of signs and miracles, so also did Jesus. And there is no doubt but that the likeness of
the signs proves him (Jesus) to be that prophet of whom he (Moses) said that he should come 'like myself' (Pseudo-Clementine, Recognitiones, 1.57).

9.Of the nine verses where $\dot{\varepsilon} \xi$ ov $\sigma i \alpha$ [authority] is found in Matthew, four occur in the miracle narratives (Mt 8:9; 9:6, 8 and 19:1). conservation and interpretation (Neusner 1979:42; Van Aarde 2011:46). The law therefore emerged as a central symbol in Jewish religion (Overman 1990:69).

It seems that Matthew firmly entered this debate on the importance of the Torah and its correct interpretation in terms of meaning and praxis.

\section{Jesus' foundational statement on the continuing validity of the Torah}

Jesus makes a very significant statement in Matthew 5:17-20. He starts off with an emphatic statement about his mission. In Matthew 5:17 Jesus uses $\tilde{\eta} \lambda \theta$ ov-sayings [I have comesayings] in parallel form to firmly state that he did not come

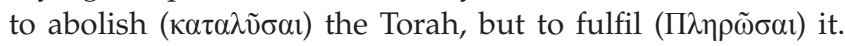
The Gospel teaches that Jesus brought and taught the intended meaning of the law. These words are probably both polemically and apologetically intended (Betz 1985:40). It seems that the message of Jesus became a matter of dispute. Matthew probably anticipated charges against his community's understanding of the law. Davies and Allison (2004a:481) describe these verses as a prokatalepsis in anticipation of possible objections.

This statement is reinforced in Matthew 5:18 with a solemn

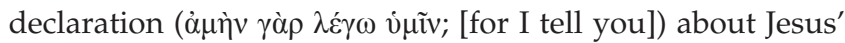
respect for even the seemingly insignificant parts of the law

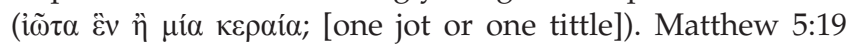
presents a double Satz heiligen Rechtes with a warning about the negative implication of setting the Torah aside and

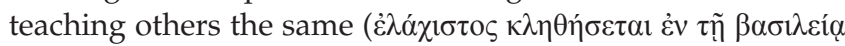
$\tau \tilde{\omega} \nu$ oủpavฮ̃v; [will be called the least in the kingdom of heaven]; Käsemann 1955:248; 1969:17). The warning is contrasted with the positive implication of practicing the

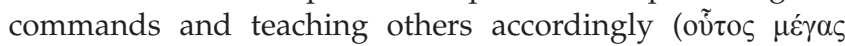

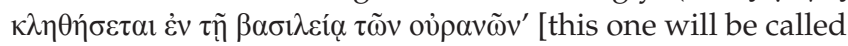
great in the kingdom of heaven]). Matthew 5:18-19 form Talionisformel [reciprocity formulas] that deal with the eschatological activity of God (Van Aarde 2011:41). The Talionisformel couple the ethical behaviour with the corresponding eschatological reward or punishment. 
The statement concludes with yet another solemn declaration in Matthew 5:20 with a Satz heiligen Rechtes, explaining the kind of righteousness that surpasses that of the Pharisees and teachers

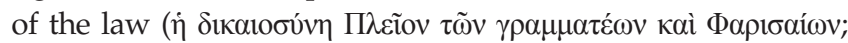
[greater righteousness than that of the teachers of the law and Pharisees]) required from disciples of Jesus. Matthew does not require a bigger and better pharisaism, or a more punctilious observance of the minute parts of the law. According to Matthew the wrong conduct of the scribes and the Pharisees ${ }^{10}$ is not the result of the quantity of their deeds, but because of their wrong understanding of the law and of a false attitude behind their deeds (Betz 1985:53). They should adhere to the different stipulations of the law, without neglect the more important matters, such as justice, mercy and faithfulness (Mt 23:23).

\section{The requirement of righteousness}

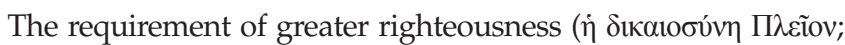
Mt 5:20) confirms the continuing validity of the Torah. The word

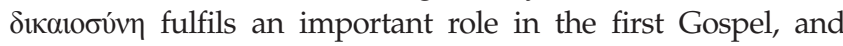
Matthew uses this word primarily with an ethical meaning.

Jesus is depicted as the righteous One who is committed to fulfil

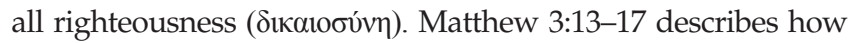
John tried to dissuade Jesus from being baptised, but that Jesus demonstrated his determination to fulfil all righteousness ( $\gamma \grave{\alpha} \rho$

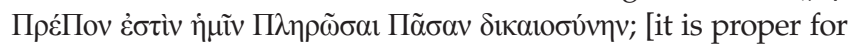
us to fulfil all righteousness]; Mt 3:15). In the synoptic Gospels only Matthew describes how John tried to dissuade Jesus from baptising him, and of how Jesus responded with this determination to fulfil all righteousness (cf. Davies \& Allison 2004a:325; Turner 2008:118). Jesus forms the prototype par excellence of one that is totally committed towards enacting God's will. Such righteousness 'characterizes proper human response to God, implying faithfulness, obedience, and ethical integrity' (Senior 1998:55). Matthew describes how the impeccable Jesus and John, his messenger, are obedient to God's will (Beare 1981:99).

The character of John demonstrates commitment to enacting God's will. Later in Matthew's narrative John is described as the

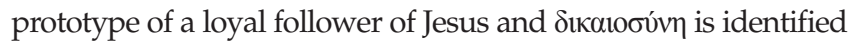
as his distinctive attribute (Mt 21:32). John came in the way of

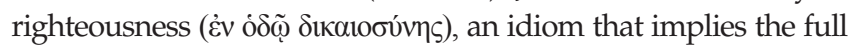
spectrum of proper response to God's will. Jesus' and John's righteous act (Mt 3:15) is balanced in this passage (Mt 21:32) about John's righteousness, forming a wide inclusio around the theme of

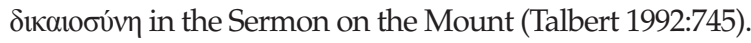

As John has acted faithfully according to God's will, Jesus' disciples are required to do the same. This is apparent from the

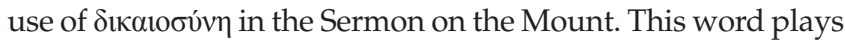
an important role in this sermon and could be considered to express the essence of this sermon (Davies \& Allison 2004a:499).

In the fourth beatitude Matthew's Jesus mentions the intense

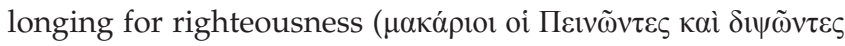

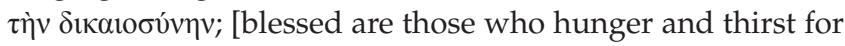
10. Matthew probably had a specific pharisaic faction in mind. It should therefore be recognised that the Pharisees are depicted from the perspective of Matthew. righteousness] as attribute of blessed ones (Mt 5:6). This implies a passionate and persistent longing for the ideal conduct in adherence to God's ordinances (Davies \& Allison 2004a:452; Spicq 2012:332; Strecker 1971:156; Turner 2008:151).

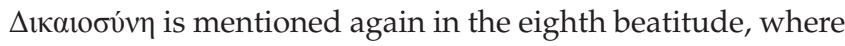

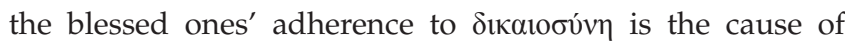
persecution (Mt 5:10). ${ }^{11}$ Matthew's Jesus speaks of those who are committed to conduct that what is appropriate for people under God's rule (Keener 2009:171).

In Matthew 6:1 Jesus urges his followers to practice their acts of

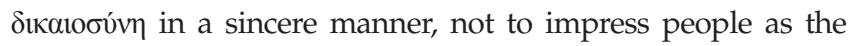
hypocrites do, but to adhere to the will of the heavenly Father. Matthew 6:1 warns against the pitfalls of practising insincere

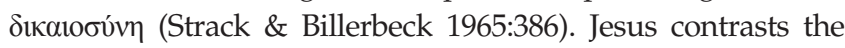
outward religious performances of the hypocrites to impress people with that of the disciples who aim to please their Father in heaven (Betz 1995:351; Davies \& Allison 2004a:579; Sim 1999:122). Three examples central to Jewish piety are mentioned, namely doing charity (Mt 6:2-4), praying (6:5-15) and fasting (6:16-18; Weren 1994:73). These acts must continue, but not in a hypocritical manner. ${ }^{12}$ The fact that sincere acts of piety are required while hypocritical acts are denounced, demonstrates that Matthew's Jesus still regards such acts as important.

In Matthew 6:33 Jesus urges his disciples to put themselves under the rule of God and constantly seek to do his will

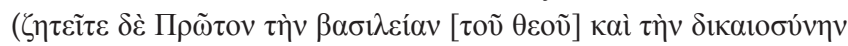

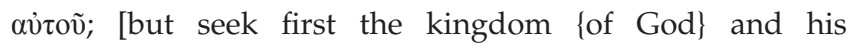
righteousness]). This implies thoroughgoing determination to continuously obey the deepest intent of the law (Mohrlang 1984:113). Betz (1995:481) fittingly regards this sentence as the telos formula and culmination of the argument on

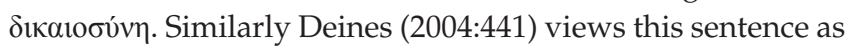
the summary of the message of the Sermon on the Mount.

\section{Jesus' halakhic argument and the continuing validity of the Torah}

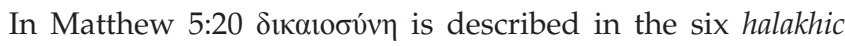
statements in Matthew 5:21-48. This form of debate urges norms of conduct with a series of theses, each introduced by

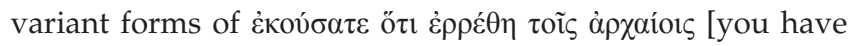
heard that it was said to or by the people long ago]; Mt 5:21, $27,31,33,38,43)$, followed by variant forms of $\dot{\varepsilon} \gamma \grave{\omega} \delta \dot{\varepsilon} \lambda \dot{\varepsilon} \gamma \omega$ vॅĩv [but I say to you]-statements by Matthew's Jesus (Mt $5: 22,28,32,34,39$, 44; Weren 1994:70). ${ }^{13}$ With an inattentive

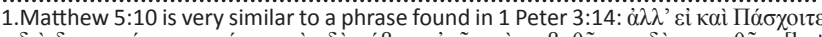

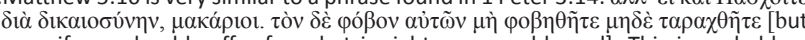
even if you should suffer for what is right, you are blessed]. This is probably a reflection of the same logion contained in oral tradition (Hagner 1992:114).

12. In an honour and shame society, one's good reputation is sustained by the esteem of others who benefit from one's public actions (Carter 2000:158; Malina \& Rohrbauch 2003:370; Witherington 2013:49). Jesus therefore opposes a fundamental societal pattern.

13.Foster (2004:80) compares Matthew 5:21-48 with the antithetical debate in the halakhic letter of Qumran (4QMMT). 4QMMT directly and indirectly makes use of the antithetical form of contrasting two opposing viewpoints in its halakhot to promote the viewpoint of the Qumran community. Similarly Matthew's Jesus also

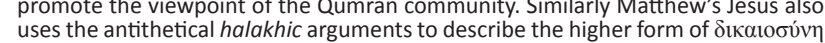
[righteousness] required from his followers. 
reading of this sixfold antithetical argument of Jesus, the conclusion can be drawn that Jesus disregarded at least some of the stipulations of the Torah. While it is clear that Jesus sharpens the meaning of the Torah in the first antithetical argument (on murder in Mt 5:21-26) and in the second (on adultery in Mt 5:27-30), there is some scholarly concern (e.g. Bornkamm 2009:16; Strecker 1971:146) that Jesus in other arguments replaces at least some of the stipulations of the Torah. However, upon careful consideration of the contextual setting of these arguments, this does not seem to be the case.

Following his foundational statement on the continuing validity of the law and its fulfilment (Mt 5:17-19), and his call for a higher form of righteousness (Mt 5:20), Jesus proceeds by arguing how the Torah continues to be valid and what this higher form of righteousness means in practice. It rather seems that Jesus objects to a literal and narrow interpretation of the Torah, since it causes the true intention of some stipulations of the law to lose their meaning (Barth 1963:93). The argument is rather that Jesus with his antithetical statements reinforces the actual and original intention of the Torah (Patte 1987:78).

Though it might seem that Jesus with his third argument (Mt 5:31-32) objects to the order of Moses to a formal certificate in case of a divorce, Jesus rather argues that the certificate was intended to protect women within the harsh reality of men who abused them, and not as a means to easily dissolve a marriage (Luz 1990:301). Jesus alludes to Deuteronomy 24:1. It is important to recognise that in this latter text divorce is assumed and not approved (France 1985:127). Moses had restricted this permission to cases where divorce de facto already has occurred. The aim of Moses' legislation 'is not to condone divorce as such, but to mitigate its evil consequences' (Stonehouse 1944:204). The original intention of Deuteronomy 24:1 was that if a man indeed divorced his wife, he was commanded to give her a certificate of the divorce. However, in due time it seems that not only the certificate as such, but also the divorce itself was regarded as demanded by Moses (cf. Mt 19:7).

Though it might seem as if Jesus in the fourth argument (Mt 5:33-37) objects against Moses' rules for the taking of oaths, it is rather that Jesus argues that the taking of oaths is only necessary in unjust societies. In the ideal and truthful society, the taking of oaths should not be necessary. ${ }^{14}$ As the necessity of taking oaths was associated with the problem of unrighteousness, it explains Jesus' total rejection of oaths for his followers, who are supposed to be righteous ${ }^{15}$ (Foster 2004:116; Morris 1992:125).

Though it might seem as if Jesus in the fifth argument (Mt 5:38-42) objects against Moses' regulation on fair (the restriction of excessive) retaliation, Jesus argues that

14.Matthew's criticism of oaths surfaces in several instances: Matthew's Jesus rejects the misuse of the Korban vow (Mt 15:3-6) and the hypocritical use of vows by the scribes and the Pharisees (Mt 23:16-22). False testimonies are brought in against Jesus during his trial (Mt 26:59-62), but when Jesus is instructed to speak under oath, he replies without an oath (Mt 26:63-64). Peter denies Jesus the second and third time under oath (Mt 26:74-74).

15.Such a prohibition of the swearing of oaths also occurs in the Damascus Document of Qumran (Vermes 1975:108). Josephus wrote about the Essenes: '... any word of theirs has more force than an oath; swearing they avoid, regarding it as worse than theirs has more force than an oath; swearing they avoid, regarding it as worse than
perjury, for they say that one who is not believed without an appeal to God stands perjury, for they say that one who is n
condemned already' (War. 2:135). retaliation should rather be avoided and be replaced by benevolence. The thought is not that evil should remain unopposed, but that evil should be answered with good (Osborne 2010:208). Followers of Jesus must refuse to stoop to the level of the aggressor by returning evil with evil (Foster 2004:125; Hagner 1993:132).

Jesus objects in the sixth argument (Mt 5:43-47) to an interpretation of the commandment of neighbourly love, which was understood in such a way that enemies could be hated. ${ }^{16}$ Jesus argues that such an understanding proves a misinterpretation of this commandment. Love even for enemies is required. The fundamental motivation for Jesus' command for enemy love is the mercy of God (Piper 1979:173). Plummer (1982:89) remarks: 'To return evil for good is devilish; to return good for good is human; to return good for evil is divine.'

The antitheses are concluded with an admonishment to be

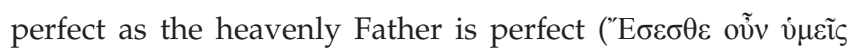

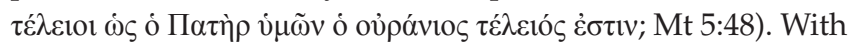
this concluding statement Jesus shows that his explication of the Torah, as described in the preceding six halakhic arguments, illustrates perfect adherence to the Torah (Osborne 2010:214). He therefore argues that believers should adhere to the true meaning of the Torah perfectly. This imperative links up with the call for greater righteousness in Matthew 5:20. The

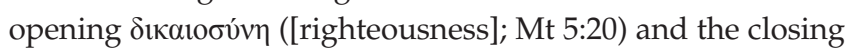

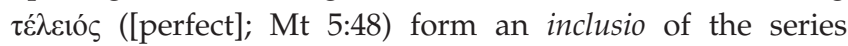
emphasising Matthew's calling for a higher ethic for his community. This standard is set by the authoritative interpretation of the law by Jesus (cf. Weren 1979:72).

\section{'Go and learn' and 'if you knew' what the Torah means}

Jesus' response to the Pharisees' objection that he ate with tax collectors and sinners (Mt 9:13) remarkably demonstrates his

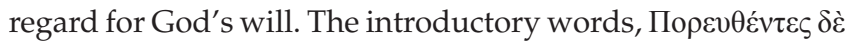

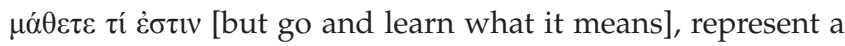
rabbinic formula to urge pupils for careful Torah study. This means that they should 'go and discern the sense of Scripture' or 'go and make a valid inference from the scriptural statement' (Davies \& Allison 2004b:104; Hill 1978:111; Osborne 2010:337). ${ }^{17}$ Jesus argues that the fact that the Pharisees accuse him of eating with the marginalised proves that they do not understand the true meaning of the Torah. In contrast he argues that what he is doing demonstrates the praxis of true adherence to God's will.

Jesus makes a similar remark about the ignorance of the

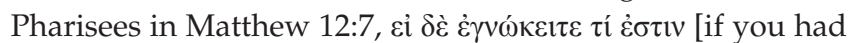
known what this means]. Jesus expresses his disappointment

\footnotetext{
16.Matthew's Jesus probably responds to the popular understanding of the love of neighbours, which in practice leads to a negative attitude towards enemies. This attitude appears strongly in the Qumran Manual: 'They may love all the sons of light ... and hate all the sons of darkness' (1 QS 1:3-4, 9-10).

17.While the Pharisees called Jesus teacher (Mt 9:11), Jesus ironically gives them a teaching assignment (Osborne 2010:227).
} 
with the fact that the Pharisees do not understand the meaning of Scripture. Green (1975:125) remarks: 'the Pharisees were so anxious to study what Scripture said that they could not hear what Scripture meant'. Jesus declares that he actually demonstrates the true intention of the Torah in the way he observes Sabbath in contrast to the ignorant interpretation of the Torah by the Pharisees, who cause a burdensome yoke on people (Mt 11:25-30). ${ }^{18}$

\section{Jesus' accusation that the Pharisees break the command of God}

Jesus' response to the Pharisees and the teachers of the law after they have accused the disciples for breaking the tradition of the elders (Mt 15:2) once again demonstrates reverence to

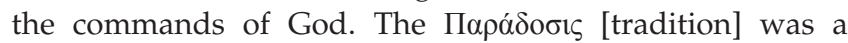
technical term referring to the collection of Jewish traditions. These traditions went beyond what was written in the Torah ${ }^{19}$ (Baumgarten 1987:66).

Jesus begins his response with 'and why do you break

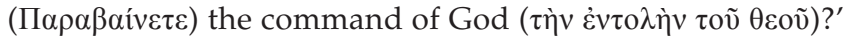

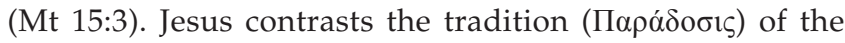
Pharisees with the command of God ( $\dot{\varepsilon} v \tau \mathrm{o} \lambda \dot{\eta})$ and the Word of God ( $\lambda$ ó $\left.{ }_{0} \varsigma\right)$. This juxtaposition intensifies the contrast between God's commandments and man-made legislation (Repschinski 2000:159). Matthew's Jesus therefore argues that his disciples do not follow the tradition of the Pharisees, because the Pharisees do not follow the commandment of God (Oliver 2013:270). The command of God is referred to as something that God said (ó yò $\theta \varepsilon$ ò $\varsigma$

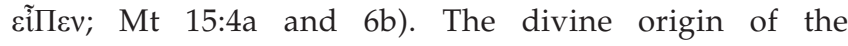
commandment is emphasised and contrasted with the

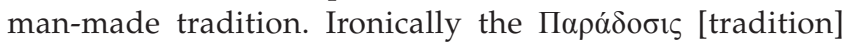
was intended to form a fence around the written Torah (Hagner 1995:430; Osborne 2010:585), but Jesus accuses the Pharisees of the fact that this very fence causes them ( $\delta i \alpha$

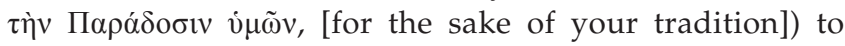
break God's commandments. Jesus argues that man-made commandments cannot substitute divine commandments. God's commandments should be respected.

It is therefore clear that Matthew is firmly committed to the adherence of the Torah in its true meaning. He does not intend to present a Jesus who brought a new or a differing law, but one for whom the Torah remains valid and important.

\section{Jesus teaches and enacts an alternative interpretation of the Torah}

While Matthew argues that the Torah remains valid, he argues that the meaning and practice of the Torah is

18.In contrast to the burdensome yoke of the Pharisees, Jesus invites people by saying $\delta \varepsilon \tilde{\tau} \tau \varepsilon$ Прó $\mu \varepsilon$ ([come to me]; Mt 11:28) and to take up his yoke, which echoes Wisdom's call (Pr 8:1-7; 9:4-5; Sir. 24:19; 51:23-27). The ultimate wisdom is to be found with him (Davies \& Allison 2004b:185).

19.In the time of Jesus the tradition was still quite fluid and the use of such tradition to apply the Torah was regarded as quite innovative (Senior 1998:176). Schiffman (1994:280-281) remarks that during the late Second Temple Judaism 'sectarian law was a living, developing phenomenon constantly giving rise to new compilations of lists of laws'. understood differently from Jewish traditions they encountered. ${ }^{20}$

\section{An alternative interpretation for an alternative community}

It seems that in the post $70 \mathrm{CE}$ period newly formed Jewish groups used the Torah to justify their parting from other groups and to define their alternative norms of existence. Their rivalry very much centred on claims to the correct interpretation of the Torah. Because of the importance of the Torah in Judaism, the interpretation of the Torah became a feature of the division. The different groups studied the law in minute thoroughness (Carter 2000:140; Cohen 2006:123; Foster 2004:2; Saldarini 1994:5). Yet, this desire to meet the specific obligations of the law, resulted in competitive disputes as to what the commandments mean in practice. Obviously this implied that other groups were doing it wrongly:

In such polemic the need for a group to find in the Torah its own self-affirmation had the inevitable corollary of making the Torah an instrument by means of which one group condemned another. (Dunn 2003:292)

In Matthew the evangelist similarly developed a subtle dialectic with his opponents. Matthew describes Jesus as the One who brought the definitive interpretation of God's will (cf. Foster 2004:28). Jesus superseded current understandings of the law with his reinterpretation thereof. Matthew narrates the story of Jesus and his disciples seemingly to defend and establish the respectability of the seemingly deviant behaviour of his community (Overman 1996:50). The Gospel challenges the conventional standards and delegitimises the religious leaders who controlled the definitions of what is considered to be normal and deviant.

\section{Jesus teaches an alternative interpretation of the Torah}

Jesus' alternative teaching of the Torah is particularly noticeable in his pronouncements on righteousness and his halakhic argument in the Sermon on the Mount.

\section{Jesus teaches an alternative form of righteousness}

The alternative teaching and praxis of the Torah is

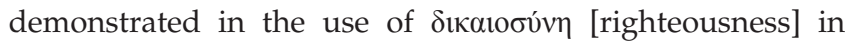

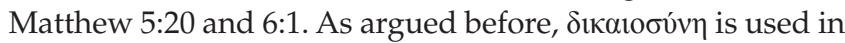
an ethical sense. The righteousness that Jesus required should in quality transcend what the scribes and Pharisees considered as righteous.

In Matthew 5:21-47 this transcending form of righteousness

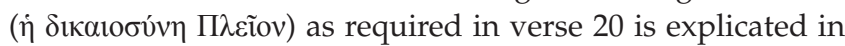
Jesus' six antithetical halakhic arguments (Osborne 2010:214).

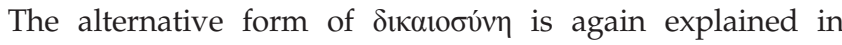
Matthew 6:1. While Matthew 5:20 deals with the nature of true

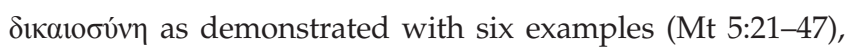

20.It should be acknowledged that for many stipulations of the law, not only one interpretation existed among the Jews. Interpretations of Jesus do show similarities interpretation existed among the Jews. Interpretations of Jesus do show similarities
with some of these interpretations. It seems, however, that the Matthean Jesus objected to some specific interpretations. 


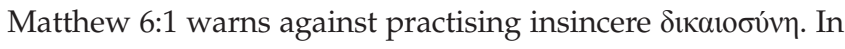
a polemical context Jesus denounces the demonstrative religious performances of the Pharisees when giving alms (Mt $6: 2-4){ }^{21}$ when praying $(6: 5-15)^{22}$ and when fasting $(6: 16-18)$ to impress people in a theatrical manner. Turner (2008) aptly remarks:

Jesus was not impressed ... with a theatrically altered appearance. Such behaviour may have been the norm for actors who sought the crowd's applause, but it is singularly inappropriate for disciples who seek the Father's approval. (p. 191)

Matthew's Jesus contrasts such theatrical conduct with the righteousness that he considers to be pleasing to the Father in heaven. The contrast does not lie in what is done, but in how it is done. The Pharisees also gave alms, prayed and fasted, but according to Matthew they did it hypocritically in order to promote their personal reputations. ${ }^{23}$ These deeds are only regarded as truly righteous if they are done with sincerity to honour God.

\section{Jesus argues six alternative interpretations of law stipulations}

Jesus' halakhic argument in Matthew 5:21-47 strongly demonstrates that Jesus teaches an alternative interpretation of the Torah. Matthew presents a series of six paragraphs, each stating a thesis followed by Jesus' interpretation of that thesis in contrast to the popular understanding of his day. ${ }^{24}$

Each of these arguments opens with a common understanding of a stipulation of the law, introduced by a repetitive formula,

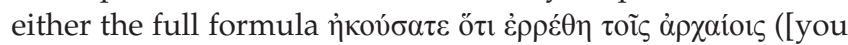
have heard that it was said to or by the people long ago];

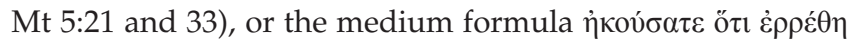
([you have heard that it was said]; Mt 5:27, 38 and 43) or the

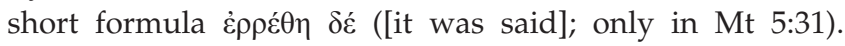
These introductions are presented in two triads (see Box 3: 'The triadic composition of the introductory formulas of the antitheses in Matthew 5:21-47').

Each of these statements is followed by an antithetical response with the definite alternative interpretation of Jesus. Jesus time and again declares $\dot{\varepsilon} \gamma \omega \grave{\delta} \delta \grave{\varepsilon} \lambda \dot{\varepsilon} \gamma \omega \dot{v} \mu \tilde{\imath} v$ [but I say to

BOX 3: The triadic composition of the introductory formulas of the antitheses in Matthew 5:21-47.

\begin{tabular}{|c|c|c|c|c|}
\hline \multicolumn{3}{|l|}{ Triad 1: } & \multicolumn{2}{|l|}{ Triad 2: } \\
\hline First: & 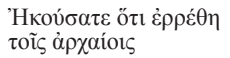 & $\longrightarrow$ & Fourth: & 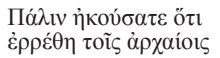 \\
\hline Second: & 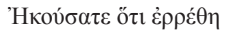 & $\longrightarrow$ & Fifth: & 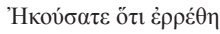 \\
\hline Third: & 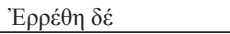 & $\longrightarrow$ & Sixth: & 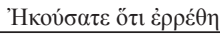 \\
\hline
\end{tabular}

21. Hands (1968:26) points out that when the wealthy helped the poor in an honour and shame culture, it was often self-regarding in that the giver anticipated more honour for one self. Almsgiving was an important means in patron-clien relationships to maintain social stratification. The wealthy would look down on the poor with ridicule.

22.Prayer is intended as communication with God and not as means to build one's reputation in front of people (Morris 1992:139).

23.The word vंПокрıтń [hypocrite] was mostly used for actors who consciously performed in a play. Batey (1971:563) indicates that Matthew consciously alludes performed in a play. Batey (1971:563) indicates that Matthew consciously alludes
to a vंПокрıtń as an actor. Performing acts of righteousness in a hypocritical manner implies that worship is turned into a spectacle.

24.The six arguments are on murder (Mt 5:21-260), adultery (5:27-30), divorce $(5: 31-32)$, oaths (5:33-37), retaliation (5:38-42) and love of enemies $(5: 43-47)$. you], implying that there are deeper principles to the law than what is commonly assumed. The dominant note hinted at by the emphatic but I tell you, is the independent, authoritative teaching of Jesus. Matthew's Jesus poses revisions in halakhah in order to better fulfil the law (Sigal 2007:70).

The antitheses are concluded with an admonishment to be perfect as the heavenly Father is perfect ('E $\sigma \varepsilon \sigma \theta \varepsilon$ oũv $\dot{v} \mu \varepsilon i \bar{\varsigma}$

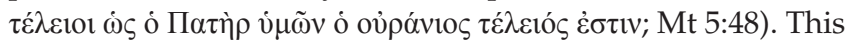
concluding statement strongly echoes Leviticus 19:2: 'Be holy because I, the Lord your God, am holy' and Deuteronomy

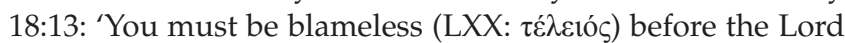
your God'. These texts imply perfect adherence to the Torah (cf. Ps 15:2; 84:11). By this concluding statement Jesus shows that his alternative explication of the Torah, as described in the preceding six halakhic arguments, illustrates perfect adherence to the Torah.

\section{Jesus enacts alternative interpretations of the Torah}

Besides his alternative teaching of the Torah, the Matthean Jesus also enacts the Torah differently. The following two short narratives serve as significant examples of this.

\section{Jesus calls a tax collector and eats with tax collectors and sinners}

Matthew 9:9-12 describes Jesus calling a 'tax collector' as a disciple and having dinner with Matthew's fellow tax collectors and sinners. Tax collectors were associated with sinners, people who in those days were regarded as shameful and impure figures in the Jewish society. ${ }^{25}$ Jesus breaks a social and religious convention not to associate with tax collectors (Osborne 2010:332). He calls Matthew the tax collector into a close relationship with him. To emphasise the point Jesus proceeds by eating with these tax collectors and sinners, presumably in Matthew's house (Mt 9:10), a place Pharisees would avoid for the sake of purity and righteousness. The way in which they eat together demonstrates fellowship with these people. The description

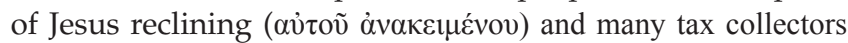

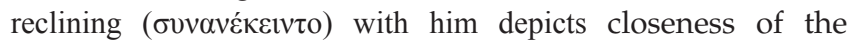
participants (Mt 9:10; Jeremias 1966:48-49). ${ }^{26}$

Through his behaviour Jesus expresses full acceptance of tax collectors and sinners. Jesus cuts the Pharisaic religious understanding and practice of who should be regarded as righteous and worthy of fellowship (Davies \& Allison 2004b:101). The Pharisees in the narrative strongly object to

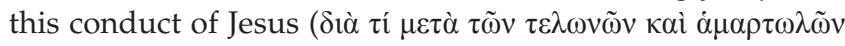

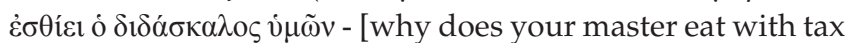
collectors and sinners?]; Mt 9:11). Table fellowship with tax collectors and sinners is depicted as objectionable to

25.Tax collectors were associated with shameful characters such as beggars, thieves

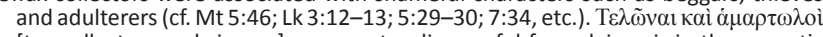
[tax collectors and sinners] represent a disgraceful formulaic pair in the synoptic Gospels (Malina \& Rohrbaugh 2003:415-416; Overman 1996:126).

26.It was custom for the Jews to sit for meals, while reclining was done at feasts and parties. The festive character of the event is thus emphasised. Table fellowship and feasting in particular were regarded as important social events and symbols of closeness of those participating (Blomberg 2005:15; Hagner 1993:238) 
Pharisaic observance of the Torah. ${ }^{27}$ In contrast to the Pharisees' religious and social preoccupations about people who they regard to be fit only for the judgement of God, Jesus fully accepts them..$^{28} \mathrm{He}$ even depicts the reason for his coming as to call such people to be healed (Mt 9:12-13). He accuses the Pharisees of ignorance of the meaning of the Scriptures for objecting to his conduct by instructing them to 'go and learn what it means: "I desire mercy, not sacrifice", (Mt 9:13a).

\section{Jesus defends the conduct of his disciples on the Sabbath}

Another clear example of Jesus' alternative enactment of the Torah is demonstrated in the controversy story about the Sabbath (Mt 12:1-13). This short narrative emphasises a basic hermeneutical difference between Jesus and the Pharisees regarding the Sabbath observance (Overman 1996:176; Turner 2008:309).

The Pharisees object to the conduct of Jesus' disciples when they pick grain on the Sabbath. In their accusation they

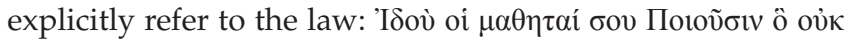

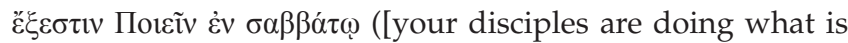
unlawful on the Sabbath]; Mt 12:2). Jesus does not dispute what the disciples have done, but challenges the Pharisees on their evaluation of the disciples' conduct. Jesus argues that God wants the expression of loving-kindness on the Sabbath, rather than blind religious practice (Lybaek 1997:493). Hummel (1966:45) remarked about this narrative: 'ES legitimiert die Freigabe des Sabbats für die Liebestat gegenüber dem Pharisäismus'.

Matthew argues this point in several ways. The Sabbath controversy is preceded by the invitation of Jesus that all who are weary and burdened should come and take his yoke upon them (Mt 11:28-30). ${ }^{29}$ Implicitly his easy and light yoke (religious practices intended to ensure adherence to the Torah) is contrasted with the burdensome practices of the Pharisees. With his citation of Hosea 6:6 ('I desire mercy and not sacrifice') in Matthew 12:7, mercy is presented as the guiding principle in religious practices. To demonstrate the point Jesus proceeds on the Sabbath to heal the man with the shrivelled hand (Mt 12:9-13).

Matthew narrates that this conduct enflames the Pharisees, as they went out to plot against Jesus to kill him (Mt 12:17). Their dismay accentuates the alternative enactment of Jesus of the Torah.

27.Pharisees were scrupulous regarding what they ate and with whom they shared their meals. For the sake of righteousness they guarded their separation from sinners (Hagner 1993:238; Morris 1992:221; Osborne 2010:336; Overman 1996:129). They were careful to keep themselves unblemished by association with those whom they regarded as sinners (Beare 1981:227). 'Keep thee far from an evi neighbour and consort not with the wicked' (Abot 1:7) was the rabbinic dictum.

28.Jesus often shared meals with such people. He therefore was accused of being a 'glutton and drunkard' and a 'friend of tax collectors and sinners' (Mt 11:9 and Lk 7:34; Sanders 1983:5-36).

29.During the Second Temple Period the term yoke was commonly used for the instruction of the Torah (e.g. 2 En. 34:1-2; 2 Apoc. Bar. 4:13; cf. Acts 15:10 and Galatians 5:1; cf. also Deines 2008:67; Hagner 1993:324; Oliver 2013:85). In Sir 6:18-31 and 51:23-27 the terms wisdom, law and yoke are linked together. The $6: 18-31$ and $51: 23-27$ the terms wisdom, law
yoke of wisdom is the instruction of the law.
This short narrative teaches that it is the divine will that mercy should be practised on the Sabbath (Carter 2000:266). If piety hinders practicing mercy, that kind of piety is wrong.

\section{Jesus defends his disciples for eating with unwashed hands}

Jesus' response to the accusation made by the Pharisees and the scribes that his disciples do not observe the tradition of hand-washing in Matthew 15:1-20 is another example of how Jesus practices the Torah differently. While the Pharisees are depicted as obsessed with external man-made rules to ensure purity, Jesus is depicted as being concerned with inner purity based on God's Word.

While the Pharisees as well as other Jewish movements except the Sadducees supplemented the written Torah with oral traditions of the elders to ensure total adherence to the Torah, Jesus rejects these traditions. With the tradition of hand-washing the Pharisees adopted the requirement set for priests before they ate consecrated food and applied these requirements to themselves and all Jews, even when eating ordinary food (Booth 1986:173; Carter 2000:316; Finklestein 1966:278; Hagner 1995:430; Neusner 1973:83; Witherington 2006:296). They want to ensure adherence to purity requirements of the Torah. Jesus, however, has no problem when ordinary people eat food with unwashed hands. In the midpoint of the story (Mt 15:11), Jesus on the one hand

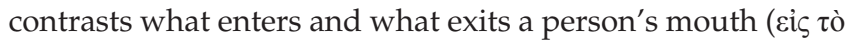

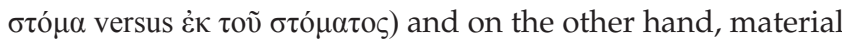
and spiritual references. Jesus transposes these external purity rituals to a requirement of internal purity. He regards internal purity as decisive. It is not what enters one's mouth that makes a person unclean, but what exits one's mouth, as it reveals the intentions of one's inner being. Things entering the mouth do not defile a person. What enters the stomach is expelled again - it does not enter the heart (only the stomach) and therefore cannot defile a person (Luz 2001:333). However, the inner thoughts of the heart define a person's integrity. Similar sentiments are found in Philo's writings, which state that impurity is primarily injustice and godlessness (Spec. leg. 3.208-209). The true character of a hypocrite (Mt 15:7) is that such a person pretends to be religious by performing outward ceremonies, but whose inner person is defiled.

\section{Conclusion}

From these observations it is obvious that the importance and interpretation of the Torah forms a central part of the argument of the first Gospel.

As the composition of the Gospel alludes to the Pentateuch and Jesus' character to that of Moses as Lawgiver, it appears that Matthew attentively presents Jesus as the superior and authoritative teacher of the Torah. In contrast to the 10 plagues in Egypt, Jesus performs healing miracles demonstrating God's salvific activity through Jesus.

Matthew argues that for Jesus the Torah continues to remain valid. He therefore enters the debate of the Jewish society of 
those days on faithfulness to the law, seemingly to defend his community's stance as followers of Jesus. He makes every effort to affirm Jesus' commitment to the Torah, e.g. with Jesus' foundational statement on the continuing validity of the Torah; the greater righteousness he requires from his disciples; his sixfold halakhic argument on specific stipulations of the law; that he instructs the Pharisees to go and learn the meaning of the Torah; and his accusation that the Pharisees are breaking the command of God with their man-made traditions.

It is, however, clear that Jesus upholds an interpretation of the Torah that differs from that of the Pharisees and teachers of the law. This probably reflects a separation of the Matthean community as followers of Jesus from other Judaistic groups of those days. Matthew's Jesus repetitively teaches righteousness that is alternative to that of the Pharisees and teachers of the law. Jesus also enacts stipulations of the law differently, which is significantly demonstrated by his association with tax collectors and sinners and his defence of his disciples' conduct on the Sabbath and eating with unwashed hands.

\section{Acknowledgements Competing interests}

The author declares that he has no financial or personal relationships which may have inappropriately influenced him in writing this article.

\section{References}

Allison, D.C., 1993, The new Moses: A Matthean typology, Clark, Edinburgh.

Bacon, B.W., 1930, Studies in Matthew, Holt, New York.

Barth, G., 1963, 'Matthew's understanding of the law', in G. Bornkamm, G. Barth \& H.J. Held (eds.), Tradition and interpretation in Matthew, pp. 58-164, Westminster Press, Philadelphia, PA.

Batey, R., 1971, 'Jesus and the theatre', New Testament Studies 30, 563-574. http:// dx.doi.org/10.1017/S0028688500013242

Baumgarten, A.I., 1987, 'The Pharisaic paradosis', Harvard Theological Review 80(1), 63-77. Beare, F.W., 1981, The Gospel according to St. Matthew: A commentary, Blackwell,
Oxford.

Betz, H.D., 1985, Essays on the Sermon on the Mount, Fortress, Philadelphia, PA.

Betz, H.D., 1995, The Sermon on the Mount including the Sermon on the Plain (Matthew 5:3-7:27 and Luke 6:20-49), Fortress, Minneapolis, MN. (Hermeneia a critical and historical commentary on the Bible).

Blomberg, C.L., 2005, Contagious holiness: Jesus' meals with sinners, InterVarsity, Downers Grove, IL. (New Studies in Biblical Theology [NSBT]).

Booth, R.P., 1986, Jesus and the laws of purity: Tradition history and legal history in Mark 7, JSOT Press, Sheffield. (Journal for the Study of the New Testament, Supplement Series, 13).

Bornkamm, G., 1963, 'The stilling of the storm in Matthew', in G. Bornkamm, G. Barth \& H.J. Held (eds.), Tradition and interpretation in Matthew, pp. 52-57, SCM, London.

Bornkamm, G., 2009, Studien zum Matthäus-Evangelium, Neukirchener Verlag, Neukirchen-Vluyn. (Wissenschaftliche Monographien zum Alten und Neuen Testament)

Carter, W., 2000, Matthew and the margins: A socio-political reading, Academic Press, Sheffield. (Journal for the Study of the New Testament, Supplement Series 204).

Cohen, S.J.D., 2006, From the Maccabees to the Mishnah, Westminster John Knox, Louisville, KY.

Combrink, H.J.B., 1983, 'The structure of the Gospel of Matthew as narrative', Tyndale Bulletin 34, 61-90.

Davies, W.D. \& Allison, D.C., 2004a, Matthew 1-7, Clark, London. (International Critical Commentary, vol. 1)

Davies, W.D. \& Allison, D.C., 2004b, Matthew 8-18, Clark, London. (International Critical Commentary, vol. 2)
Deines, R., 2004, Die Gerechtigkeit der Tora im Reich des Messias: Mt 5,13-20 als Schlüsseltext der matthäischen Theologie, Mohr Siebeck, Tübingen. Schlüseltext der matthaischen Theologie, Mohr Sieb
(Wissenschaftliche Untersuchungen zum Neuen Testament 177).

Deines, R., 2008, 'Not the law but the Messiah: Law and righteousness in the Gospel of Matthew - An ongoing debate', in D.M. Gurtner \& J. Nolland (eds.), Built upon the rock: Studies in the Gospel of Matthew, pp. 53-84, Eerdmans, Built upon the rock:
Grand Rapids, MI.

Dunn, J.D.G., 2003, Jesus remembered: Christianity in the making, vol. 1, Eerdmans, Grand Rapids, MI.

Evans, C.A., 2012, Matthew, Cambridge University Press, Cambridge. (New Cambridge Bible Commentary).

Finklestein, I., 1966, The Pharisees, Jewish Publication Society, Philadelphia, PA.

Floor, L., 1969, De nieuwe exodus: Representatie en inkorporatie in het Nieuwe Testament, Ph.D. thesis, Faculty of Theology, PU for CHE, Potchefstroom.

Foster, P., 2004, Community, law and mission in Matthew's Gospel, Mohr Siebeck, Tübingen. (Wissenschaftliche Untersuchungen zum Neuen Testament, 2, Reihe 177)

France, R.T., 1985, Matthew, InterVarsity, Nottingham. (Tyndale New Testament Commentaries).

Green, H.B., 1975, The Gospel according to Matthew in the Revised Standard Version, The New Clarendon Bible, Oxford University Press, London.

Grundmann, W., 1971, Das Evangelium nach Matthäus: Theologischer Handkommentar zum Neuen Testament 1, Evangelische Verlagsanstalt, Berlin.

Hagner, D.A., 1992, 'Righteousness in Matthew's theology', in M.J. Wilkens \& T. Paige (eds.), Worship, theology and ministry in the Early Church, pp. 101-120, JSOT Press, Sheffield. (Journal for the Study of the New Testament, Supplement Series 87).

Hagner, D.A., 1993, Matthew 1-13, Word Books, Dallas, TX. (Word Biblical Commentary, 33A).

Hagner, D.A., 1995, Matthew 14-28, Word Books, Dallas, TX. (Word Biblical Commentary, 33B).

Hands, A.R., 1968, Charities and social aid in Greece and Rome, Cornell University Press, New York.

Hill, D., 1978, 'On the use and meaning of Hosea 6:6 in Matthew's gospel', New Testament Studies 24(1), 107-119. http://dx.doi.org/10.1017/S002868850000 3799

Hummel, R., 1966, Die Auseinandersetzung zwischen Kirche und Judentum im Matthäusevangelium, Kaisar, München.

Jeremias, J., 1966, Eucharistic words of Jesus, Fortress, Philadelphia, PA.

Käsemann, E., 1955, 'Sätze Heiligen Rechtes im Neuen Testament', New Testament Studies 1, 248-260. http://dx.doi.org/10.1017/S0028688500005476

Keener, G.S., 2009, The Gospel of Matthew: A socio-rhetorical commentary, Eerdmans, Grand Rapids, Ml.

Kingsbury, J.D., 1988, Matthew as story, Fortress, Philadelphia, PA.

Klostermann, E., 1927, Das Mattäusevangelium: Handbuch zum Neuen Testament, Mohr Siebeck, Tübingen.

Loader, W.R.G., 1997, Jesus' attitude towards the law: A study of the Gospels, Mohr Siebeck, Tübingen. (Wissenschaftliche Untersuchungen zum Neuen Testament 2. Reihe).

Luz, U., 1990, Matthew 1-7: A commentary, Clark, Edinburgh.

Luz, U., 2001, Matthew 8-20: A commentary, Fortress, Minneapolis, MN.

Lybaek, L., 1997, 'Matthew's use of Hosea 6.6 in the context of the Sabbath controversies', in C.M. Tuckett (ed.), The Scriptures in the Gospels, pp. 491-499, Peeters, Leuven.

Malina, B.J. \& Rohrbauch, R.L., 2003, Social-science commentary on the synoptic Gospels, Fortress, Minneapolis, MN.

Meier, J.P., 1976, Law and history in Matthew's Gospel, Biblical Institute Press, Rome.

Meier, J.P., 2009, A marginal Jew: Rethinking the historical Jesus, vol. 4: Love and Law, Yale University Press, New Haven, CT.

Mohrlang, R., 1984, Matthew and Paul: A comparison of ethical perspectives, University Press, Cambridge. (Society for New Testament Studies, Monograph Series, 48)

Morris, L., 1992, The Gospel according to Matthew, Eerdmans, Grand Rapids, MI.

Neusner, J., 1973, From politics to piety: The emergence of Pharisaic Judaism, Prentice Hall, Englewood Cliffs, NJ.

Neusner, J., 1979, 'The formation of Rabbinic Judaism: Yavneh form 70-100', in H. Temporini \& W. Haase (eds.), Aufstieg und Niedergang der Römischen Welt: Geschichte und Kultur Roms im Spiegel der Neueren Forshung, pp. 3-42, Walter de Gruyter, Berlin.

Oliver, I.W., 2013, Torah praxis after 70 ce: Reading Matthew and Luke-Acts as Jewish texts, Mohr Siebeck, Tübingen.

Osborne, G.R., 2010, Matthew, Zondervan, Grand Rapids, MI. (Zondervan exegetical commentary on the New Testament).

Overman, J.A., 1990, Matthew's Gospel and formative Judaism: The social world of the Matthean community, Fortress, Minneapolis, MN.

Overman, J.A., 1996, Church and community in crisis: The Gospel according to Matthew, Trinity Press International, Harrisburg, PA. 
Patte, D., 1987, The Gospel according to Matthew: A structural commentary on Matthew's faith, Fortress, Philadelphia, PA.

Piper, J., 1979, 'Love your enemies': Jesus' love command in the synoptic Gospels and the early Christian paraenesis, Cambridge University Press, Cambridge. (Society for New Testament Studies monograph series, 38).

Plummer, A., 1982 [1909], An exegetical commentary of the Gospel according to St. Matthew, Baker, Grand Rapids, MI.

Repschinski, B., 2000, The controversy stories in the Gospel of Matthew: Their redaction, form and relevance for the relationship between the Matthean community and formative Judaism, Vandenhoeck \& Ruprecht, Göttingen.

Saldarini, A.J., 1994, Matthew's Christian-Jewish community, University of Chicago Press, Chicago, IL.

Sanders, E.P., 1983, 'Jesus and the sinners', Journal for the Study of the New Testament 19, 5-36. http://dx.doi.org/10.1177/0142064X8300601902

Schiffman, L., 1994, Reclaiming the Dead Sea Scrolls, Jewish Publication Society of America, Philadelphia, PA.

Senior, D., 1998, Matthew, Abingdon New Testament Commentaries, Abingdon Press, Nashville, TN.

Sigal, P., 2007, The halakhah of Jesus of Nazareth according to the Gospel of Matthew, Brill, Leiden. (Studies in Biblical Literature, 18).

Sim, D.C., 1999, The Gospel of Matthew and Christian Judaism: The history and social setting of the Matthean Community, Clark, Edinburg, TX.

Spicq, C., 2012, Theological lexicon of the New Testament, vol. 1, Hendrikson, Peabody, $\mathrm{MA}$
Stonehouse, N.B., 1944, The witness of Matthew and Mark to Christ, Tyndale, London. Strack, H.L. \& Billerbeck, P., 1965, Kommentar zum Neuen Testament aus Talmud und Midrasch, Beck, München.

Strecker, G., 1971, Der Weg der Gerechtigkeit: Untersuchung zur Theologie des Matthäus, Vandenhoeck \& Ruprecht, Göttingen.

Talbert, C.H., 1992, 'Biography, Ancient', in D.N. Friedman (ed.), The Anchor Bible Dictionary, pp. 745-749, Doubleday, New York.

Talbert, C.H., 2010, Matthew, Baker Academic, Grand Rapids, MI. (Paideia commentaries on the New Testament).

Turner, D.L., 2008, Matthew: Baker exegetical commentary of the New Testament, Baker Academic, Ada Township, MI.

Van Aarde, A., 2011, "'On earth as is in heaven" - Matthew's eschatology as the kingdom of heavens that has come', in J.G. van der Watt (ed.), Eschatology of the New Testament and some related documents, pp. 35-63, Mohr Siebeck, Tübingen. (Wissenschaftliche Untersuchungen zum Neuen Testaments, 2:315).

Vermes, G., 1975, The Dead Sea Scrolls in English, Penguin, New York.

Weren, W.J.C., 1979, De broeders van de Mensenzoon: Mt 25, 31-46 als toegang tot de eschatologie van Matteus, Bolland, Amsterdam.

Weren, W.J.C., 1994, Belichting van het Bijbelboek: Matteüs, Katholieke Bijbelstichting, 's-Hertogenbosch.

Witherington, B., 2006, Matthew, Smyth \& Helwys Bible commentary, vol. 19, Smyth \& Helwys Publishing, Macon.

Witherington, B., 2013, Invitation to the New Testament: First things, Oxford University Press, Oxford. 